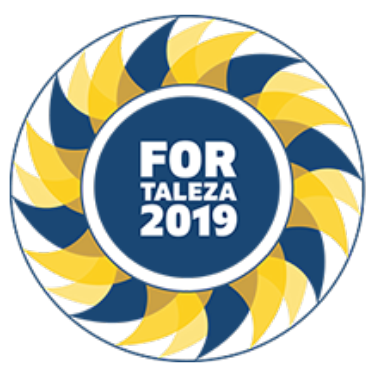

\title{
MAJOR SALIVARY GLAND ULTRASONOGRAPHY IS ASSOCIATED WITH HISTOLOGICAL ANALYSIS, AUTOANTIBODIES AND GLANDULAR DYSFUNCTION IN PRIMARY SJOGREN'S SYNDROME
}

ÉRICA VIEIRA SERRANO (UNIVERSIDADE FEDERAL DO ESPIRITO SANTO, VITORIA, ES, Brasil), LUCAS DOS SANTOS BRAGANÇA (UNIVERSIDADE FEDERAL DO ESPIRITO SANTO, VITORIA, ES, Brasil), KETTY LYSIE LIBARDI LIRA MACHADO (UNIVERSIDADE FEDERAL DO ESPIRITO SANTO, VITORIA, ES, Brasil), SÁVIO CARVALHO DEOTTI (UNIVERSIDADE FEDERAL DO ESPIRITO SANTO, VITORIA, ES, Brasil), Thallys Henrique ALVES PEREIRA (UNIVERSIDADE FEDERAL DO ESPIRITO SANTO, VITORIA, ES, Brasil), VALÉRIA VALIM (UNIVERSIDADE FEDERAL DO ESPIRITO SANTO, VITORIA, ES, Brasil)

\section{BACKGROUND}

Ultrasonography (US) of salivary glands (SG) has comparable specificity to labial biopsy, which may increase the sensitivity and accuracy of primary Sjögren's Syndrome (pSS) diagnosis by assessing the echogenicity and homogeneity of the glands. Aim of this study is to describe the findings of the US of SG in patients of a reference center in SSp and to compare with clinical and histological data.

\section{MATERIALS AND METHODS}

Descriptive cross-sectional study of pSS patients from a University Hospital submitted to US of major GS using US ESAOTE My Lab 70, linear transducer, mode B frequency $12 \mathrm{MHz}$. The Hammenfors 2015 scoring system US was used to evaluate the echogenicity and homogeneity in the 4 largest SG in the 0-3 scale: 01 is normal/non-specific; and 2-3 is abnormal/typical of SS. Clinical data were obtained from this institution's pSS record.

\section{RESULTS}

78 subjects, mean age 51 years $( \pm 10 S D)$, most of them women $92 \%(n=72)$, mean diagnosis time 5.3 years $( \pm 3.5$ SD) and $90 \%(n=70)$ evaluated to ACR-EULAR 2016 criteria. Objective ocular dryness by Schirmer I test in $65 \%(n=50)$; salivary flow $<0.1 \mathrm{ml} / \mathrm{min}$ in $53 \%(n=39)$, anti-Ro positive in $73 \%(n=57)$, anti-La in 33\% ( $n=25)$, rheumatoid factor (RF) in $42 \%(n=27)$, hypocomplementemia (low C3) in $12 \%$ ( $n$ $=9$ ) and labial biopsy positive in $58 \%(n=43)$. The typical changes to the US (scores $2-3$ ) occurred in $49 \%$ $(n=38)$, predominance in submandibular $54 \%(n=42)$ compared to $31 \%(n=24)$ of the parotid. Two groups were separated: typical US (scores 2-3), and non-specific (US scores 0-1) and correlated to data and histology of labial minor SG. There was a statistically significant difference between the two groups for: positive schirmer test $(p=0.01)$, positive unstimulated whole salivary flow (UWSF $<0.1 \mathrm{ml} / \mathrm{min})(p=$ $0.04)$, anti-Ro $(p=0.0001)$, anti-La $(p=0.007)$ and positive RF $(p=0.04)$ (Fisher test). The for continuous variables: lower age (mean age 48 years) $(p=0.04)$, higher focus score on biopsy (mean of 1.23$)(p=0.03)$, low UWSF ( $p=0.02)$, lower C3 ( $p=0.001)$ and higher activity score in the biological domain of the ESSDAI $(p=0.01)$ (Student's t-test).

\section{CONCLUSION}

SG scores 2 - 3 correlated with younger age, objective dryness tests, autoantibodies, complement consumption, hypergammaglobulinemia and focus score on the labial biopsy. 